\title{
PENGARUH RISIKO OPERASIONAL DAN TINGKAT KECUKUPAN MODAL TERHADAP PROFITABILITAS PADA BANK UMUM SWASTA NASIONAL DI BURSA EFEK INDONESIA PERIODE 2015-2019
}

\author{
Krisma Aprilita Yuniar \\ E-mail: krismaaprilita47@gmail.com \\ Gusganda Suria Manda \\ E-mail: gusganda.suriamanda@fe.unsika.ac.id \\ (Program Studi S1 Akuntansi, Fakultas Ekonomi, Universitas Singaperbangsa Karawang)
}

\begin{abstract}
ABSTAK: Bank adalah lembaga keuangan yang kegiatannya menghimpun dana (uang) dari masyarakat dalam bentuk simpanan. Profitabilitas suatu bank dipengaruhi oleh beberapa faktor, antara lain risiko operasional dan tingkat kecukupan modal. Tujuan penelitian ini adalah untuk mengetahui pengaruh Risiko Operasional dan Rasio Kecukupan Modal terhadap Profitabilitas pada Bank Milik Swasta Nasional yang terdaftar di Bursa Efek Indonesia periode 2015-2019. Penelitian ini menggunakan populasi sebanyak 6 bank swasta yang terdaftar di BEI dengan jumlah 30, pengambilan sampel di BEI diakses melalui website www.idx.co.id dan data yang diperoleh berupa Laporan Tahunan Bank Swasta yang dipublikasikan. Teknik analisis data yang digunakan adalah Analisis Deskriptif, Uji Asumsi Klasik, Analisis Regresi Linier Berganda dan Uji Hipotesis (uji $t$ dan f). Hasil penelitian ini menunjukkan bahwa risiko operasional berpengaruh negatif signifikan terhadap profitabilitas, dan tingkat kecukupan modal berpengaruh positif signifikan terhadap profitabilitas.
\end{abstract}

Kata kunci: Bank, Risiko Operasional, Rasio Kecukupan Modal dan Profitabilitas

\begin{abstract}
Banks are financial institutions whose activities are to collect funds (money) from the public in the form of deposits. Profitability in a bank is influenced by several factors, including operational risk and the level of capital adequacy. The purpose of this study was to determine the effect of Operational Risk and Capital Adequacy Ratio on Profitability at Bank Milik Swasta Nasional listed on the Indonesian Stock Exchange for the period 2015-2019. This study uses a population of 6 private banks listed on the IDX with a total of 30, sampling on the IDX accessed through the website www.idx.co.id and data obtained in the form of published Private Bank Annual Report. The data analysis technique used is Descriptive Analysis, Classical Assumption Test, Multiple Linear Regression Analysis and Hypothesis Test ( $t$ and $f$ test). The results of this study indicate that operational risk has a significant negative effect on profitability, and the level of capital adequacy has a significant positive effect on profitability.
\end{abstract}

Keywords: Banks, Operational Risk, Capital Adequacy Ratio and Profitability 


\section{PENDAHULUAN}

Keberadaan zona perbankan memiliki kedudukan sangat berarti terhadap kelancaran dalam membangun perekonomian di suatu negeri, dimana zona ini menolong bank dalam menghimpun serta menyalurkan dana yang diberikan oleh pihak- pihak yang mempunyai kelebihan dana maupun kekurangan dana. Dengan peranannya tersebut, bank sudah jadi lembaga yang ikut mempengaruhi pertumbuhan perekonomian suatu negeri. (Prasetyo \& Darmayanti, 2015)

Risiko operasional ialah risiko yang diakibatkan oleh kurang berfungsinya proses internal bank, human error, kegagalan sistem teknologi, ataupun akibat kasus eksternal. Menurut Dendawijaya (2009:98) ratio biaya operasional digunakan untuk mengukur tingkat efisiensi dan kemampuan bank dalam melakukan kegiatan operasinya. Risiko operasional pada umumnya menggunakan BOPO (Beban Operasional terhadap Pendapatan operasional) sebagai indikator penelitan. (Ratio, 2016)

Tingkat kecukupan modal yang memadai dapat melindungi sebuah bank ketika mengalami kerugian dari aktivitas operasional yang tidak terduga (Anjani, 2014). Capital Adequacy Ratio (CAR) merupakan proksi untuk mengukur pemenuhan kewajiban permodalan suatu bank. ROA bank seharusnya mengalami peningkatan dari waktu ke waktu, namun hal itu tidak terjadi pada Bank Umum Swasta Nasional. Berdasarkan peraturan Bank Indonesia No.15/12/PBI/2013, permodalan minimum E-Jurnal Manajemen Unud, Vol. 4, No. 4, 2015: 2590-2617 2595 yang harus dimiliki oleh suatu bank adalah $8 \%$. Tidak hanya bagaikan sumber utama pembiayaan terhadap aktivitas operasional, permodalan pula berperan bagaikan suatu fondasi untuk bank itu sendiri terhadap kemungkinan terbentuknya kerugian. Profitabilitas ialah keahlian bank buat mendapatkan laba dari aktivitas pembedahan nya. Dimensi profitabilitas yang digunakan merupakan Return On Asset( ROA). (Wahyuni Pratiwi \& Wiagustini, 2016)

Adapun permasalah yang ingin dikaji dalam penelitian ini adalah: 1). Apakah risiko operasional berpengaruh signifikan terhadap profitabilitas pada bank umum swasta nasional? 2). Apakah tingkat kecukupan modal berpengaruh signifikan terhadap profitabilitas pada bank umum swasta nasional? 3). Bagaimana risiko operasional dan tingkat kecukupan modal berpengaruh secara simultan terhadap profitabilitas pada bank umum swasta nasional?

Maka penelitian ini bertujuan pertama, untuk mengetahui signifikansi pengaruh risiko operasional terhadap profitabilitas pada bank umum swasta nasional periode. Kedua, mengetahui signifikansi pengaruh tingkat kecukupan modal terhadap profitabilitas pada bank umum swasta nasional. Ketiga, mengetahui bagaimanakah risiko operasional dan tingkat kecukupan modal berpengaruh secara simultan terhadap profitabilitas pada bank umum swasta nasional.

Oleh karena itu, penulis tertarik untuk mengukur, menganalisa dan melakukan riset berskala kecil dan mengangkat judul "PENGARUH RISIKO OPERASIONAL DAN TINGKAT KECUKUPAN MODAL TERHADAP PROFITABILITAS PADA BANK UMUM SWASTA NASIONAL DI BURSA EFEK INDONESIA PERIODE 2015-2019".

\section{TINJAUAN PUSTAKA}

\section{Bank}

\section{- Pengertian}

Menurut Kasmir (2012:12) bank merupakan lembaga keuangan yang kegiatannya menghimpun dana dari masyarakat dalam bentuk simpanan kemudian menyalurkan kembali ke masyarakat, serta memberikan jasa-jasa kepada bank lainnya. Menurut UU No. 10 tahun 1998 tentang perbankan indonesia: "Bank adalah badan usaha yang menghimpun dana dari masyarakat dalam bentuk simpanan, dan menyalurkannya kepada masyarakat dalam rangka meningkatkan tarif hidup rakyat banyak." 
Dari penafsiran di atas bisa disimpulkan bahwa bank ialah lembaga keuangan yang kegiatannya yaitu: Menghimpun dana (uang) dari masyarakat dalam wujud simpanan, dan dalam perihal ini bank selaku tempat menyimpan uang ataupun berinvestasi untuk masyarakat.

\section{- Jenis - Jenis Bank}

Jenis perbankan dewasa ini berdasarkan undang-undang RI nomor 10 tahun 1990 antara lain: (Kasmir, 2014)

\section{a. Dilihat dari segi fungsinya}

1) Bank Umum Bank umum adalah bank yang melaksanakan kegiatan usahanya secara konvensional dan atau berdasarkan prinsip syariah yang dalam kegiatannya memberikan jasa dalam lalu lintas pembayaran.

2) Bank Perkreditan Rakyat (BPR) Bank perkreditan rakyat (BPR) adalah bank yang melaksanakan kegiatan usahanya secara konvensional atau berdasarkan prinsip syariah yang dalam kegiatannya tidak memberikan jasa dalam lalu lintas pembayaran.

\section{b. Dilihat dari segi kepemilikannya}

Ditinjau dari segi kepemilikan misalnya adalah siapa saja yang memiliki bank tersebut. Kepemilikan ini dulihat dari akte pendirian dan pengusaha saham yang dimiliki bank yang bersangkutan. Jenis bank dilihat dari segi kepemilikan tersebut adalah :

1) Bank milik pemerintah, dimana bank akte pendirian maupun modalnya dimiliki oleh pemerintah, sehingga seluruh keuntungan bank ini dimiliki oleh pemerintah pula.

2) Bank milik swasta nasional, bank jenis ini seluruh atau sebagian besarnya dimiliki oleh swasta nasional serta akte 7 pendiriannya pun dimiliki oleh swasta. Begitu pula pembagian keuntungannya untuk keuntungan swasta pula.

3) Bank milik koperasi, kepemilikan saham-saham ini dimiliki olehperusahaan yang berbeda hukum koperasi.

4) Bank milik asing, bank jenis ini merupakan cabang dari bank yang ada diluarnegeri, bank milik swasta asing atau pemerintah asing. Kepemilikannya dimiliki oleh pihak luar negeri.

5) Bank milik campuran, kepemilikan saham bank campuran dimiliki olehpihak asing dan pihak swasta nasional. Kepemilikan sahamnya secara mayoritas dipinjam oleh Warga Negara Indonesia.

\section{c. Dilihat dari segi status}

Status bank yang dimaksud adalah :

1) Bank devisa. Merupakan bank yang dapat melaksanakan transaksi ke luarnegeri atau yang berhubungan dengan mata uang asing secara keseluruhan.

2) Bank nondevisa. Merupakan bank yang belum mempunyai izin untuk melaksanakan transaksi sebagai bank devisa, sehingga tidak dapat melaksanakan transaksi seperti bank devisa. Dimana transaksi yang dilakukan masih dalam batasbatas Negara.

\section{d. Dilihat dari segi menentukan harga}

1) Bank yang berdasarkan prinsik konvensional.

2) Bank yang berdasarkan prinsip syariah, aturan perjanjian berdasarkan hukum Islam antara bank dengan pihak lain untuk menyimpan dana atau pembiayaan usaha atau kegiatan perbankan lainnya. 
e. Dilihat dari fungsi dan tujuan usahanya

1) Bank Central.

Bank central adalah bank yang bertindak sebagai bankers bank pimpinan penguasa moneter, mendorong dan mengarahkan semua jenis bank yang ada.

2) Bank Umum.

Bank umum adalah bank milik negara, swasta, maupun koperasi yang dalam pengumpulan dananya terutanma menerima simpanan dalam bentuk giro, deposito, serta tabungan dan dalam usahanya terutama memberikan kredit jangka pendek.

3) Bank Tabungan.

Bank tabungan adalah bank milik negara, swasta maupun koperasi yang dalam pengumpulan dananya terutama menerima simpanan dalam bentuk tabungan sedangkan usaha terutama memperbanyak dana dengan kertas berharga.

4) Bank Pembangunan.

Bank pembangunan adalah bank milik negara, swasta maupun koperasi yang dalam pengumpulan dananya terutama menerima simpanan dalam bentuk deposito dan mengeluarkan kertas berharga jangka menengah dan panjang. Sedangkan usahanya terutama memberikan kredit jangka menengah dan panjang. Dibidang pembangunan. (Anita, 2016)

\section{Bank Milik Swasta Nasional}

Bank milik swasta nasional adalah bank yang sebagian besar sahamnya serta akta pendiriannya pun milik pihak swasta. Bank milik swasta ini dibedakan menjadi dua yaitu bank swasta nasional devisa dan bank swasta nasional non devisa. Contoh dari bank milik swasta diantaranya adalah Bank Muamalat, Bank Central Asia, Bank Bumi Putera, Bank Danamon, Bank Niaga, Bank Mega dan lain sebagainya.

\section{Risiko Operasional (BOPO)}

Risiko operasional didefinisikan sebagai risiko kerugian atau ketidakcukupan dari proses internal, sumber daya manusia, dan sistem yang gagal atau dari peristiwa eksternal (Idroes, 2011:23). Dapat dijelaskan risiko operasional adalah kerugian dari kegagalan operasional, hal ini mencakup berbagai peristiwa dan tindakan tertentu. BOPO merupakan rasio yang digunakan untuk mengukur kemampuan manajemen bank dalam mengendalikan biaya operasional terhadap pendapatan operasional (Hariyani, 2010:54). Dalam Surat Edaran Bank Indonesia No.15/7/DPNP tanggal 8 Maret 2013 dijelaskan bahwa rasio BOPO yang harus dijaga bank umum tidak lebih dari 85\%. BOPO yang besar akan menurunkan CAR, dan BOPO yang rendah akan meningkatkan CAR.

$$
\mathrm{BOPO}=\frac{\text { Biaya Operasional } \times 100 \%}{\text { Pendapatan Operasional }}
$$

\section{Kecukupan Modal (CAR)}

Pemodalan menunjukkan kemampuan manajemen bank untuk mengawasi serta mengontrol risiko yang terjadi, yang bisa mempengaruhi besarnya modal bank (Prastiyaningtyas, 2010). Kecukupan modal pada tercermin pada Capital Adequacy Ratio (CAR). CAR di atas 8\% menunjukkan usaha bank yang semakin stabil, karena adanya kepercayaan masyarakat yang besar. Dapat disimpulkan bahwa tingkat kecukupan modal (CAR) sangat berpengaruh signifikan terhadap Profitabilitas (ROA). 


\section{Profitabilitas (ROA)}

Menurut Harahap (2008:304) profitabilitas adalah kemampuan perusahaan mendapatkan laba melalui semua kemampuan dan sumber yang ada seperti kegiatan penjualan, kas, modal, jumlah karyawan, jumlah cabang, dan sebagainya. Laba perusahaan merupakan untuk mengukur kinerja perusahaan, dimana ketika perusahaan mempunyai laba yang tinggi berarti kinerjanya baik dan sebaliknya.

Ada beberapa indikator rasio profitabilitas yang dapat digunakan untuk mengukur kemampuan perusahaan dalam memperoleh laba, antara lain:

Return on Assets adalah rasio ini mengukur kemampuan perusahaan untuk menghasilkan laba bersih berdasarkan tingkat aset yang tertentu (Hanafi dan Halim, 2007:84). Return on assets (ROA) dapat dihitung dengan rumus sebagai berikut:

\section{ROA = Laba Setelah Pajakx 100\%}

Total Aktiva

\section{Pengaruh BOPO terhadap ROA}

Biaya Operasional terhadap Pendapatan Operasional (BOPO) merupakan rasio keuangan yang membandingkan antara biaya operasional dengan pendapatan operasional. Semakin kecil Biaya Operasional terhadap Pendapatan Operasional (BOPO) maka semakin efisien biaya operasional yang dikeluarkan perusahaan yang besangkutan (Almilia dan Herdiningtyas, 2005). BOPO berpengaruh negatif terhadap ROA, karena jika BOPO mengalami peningkatan maka telah terjadi peningkatan pada total beban operasional dengan persentase lebih besar dibandingkan dengan persentase kenaikan pendapatan operasional. Yang mengakibatkan laba mengalami penurunan dan ROA turun.

Menurut ketentuan Bank Indonesia efisiensi operasi diukur dengan BOPO/Biaya Operasional Pendapatan Operasional dengan batas maksimum BOPO/ Biaya Operasional Pendapatan Operasional adalah $85 \%$.

\section{Pengaruh tingkat CAR terhadap ROA}

CAR/Capital Adequacy Ratio merupakan ratio permodalan yang menunjukkan kemampuan bank dalam menyediakan dana untuk keperluan pengembangan usaha dan menampung risiko kerugian dana yang diakibatkan oleh kegiatan operasi bank (Ali 2004 :264). Dapat di simpulkan bahwa CAR/Capital Adequacy Ratio merupakan ratio permodalan yang menunjukkan kemampuan bank dalam menyediakan dana untuk keperluan pengembangan usaha dan menampung risiko kerugian dana yang diakibatkan oleh kegiatan operasi bank. Dan berpengaruh positif secara signifikan terhadap ROA.

\section{Kerangka Pikiran}

Berdasarkan penjelasan kerangka teori maka dapat disederhanakan dalam bentuk kerangka pemikiran. Secara konseptual dapat digambarkan Risiko Operasional (BOPO) dan Kecukupan Modal (CAR) diduga berpengaruh terhadap Profitabilitas (ROA) sebagai berikut: 


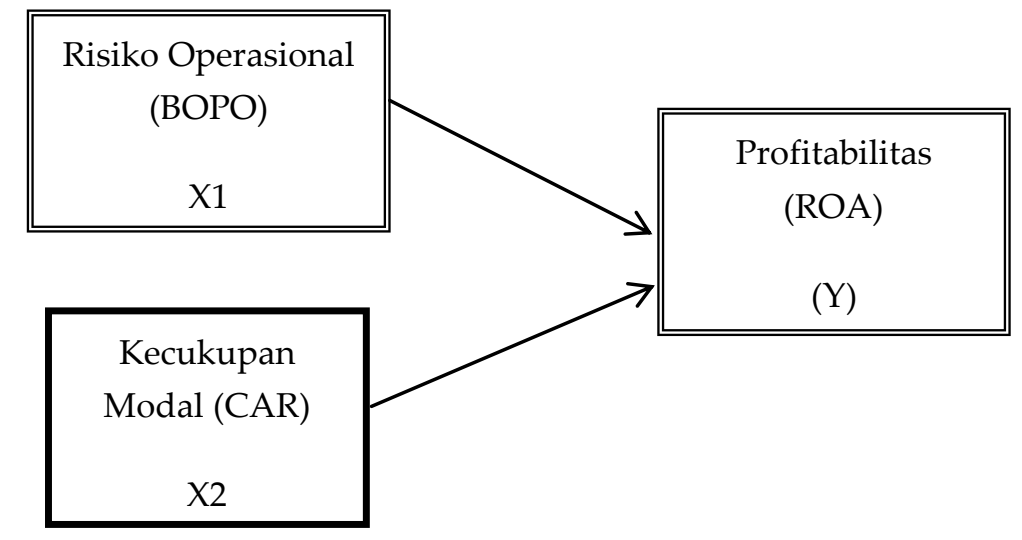

\section{Gambar 1. Kerangka Pikir}

Keterangan:

1. Pengaruh variabel Risiko Operasional (X1) terhadap Profitabilitas (Y)

2. Pengaruh variabel Kecukupan Modal (X2) terhadap Profitabilitas (Y)

\section{Hipotesis}

Hipotesis merupakan jawaban sementara dari rumusan masalah penelitian. Dikatakan sementara karena anggapan mungkin benar atau tidak dan dan sering digunakan sebagai dasar pembuatan keputusan pemecahan persoalan ataupun untuk dasar penelitian lebih lanjut. Didasarkan pada teori relevan belum pada fakta -fakta empiris. (Sugiyono, 2015)

Atas dasar tinjauan pustaka dan kerangka pemikiran teoritis di atas, maka hipotesis dari penelitian ini adalah sebagai berikut:

H1: Risiko Operasional berpengaruh negatif secara signifikan terhadap Profitabilitas (ROA).

H2: Kecukupan Modal berpengaruh secara signifikan terhadap Profitabilitas (ROA).

H3: Terdapat pengaruh Risiko Operasional dan Kecukupan Modal secara simultan terhadap Profitabilitas (ROA).

\section{METODE PENELITIAN}

Penelitan dilakukan pada Bank Milik Swasta Nasional di Indonesia. Obyek dari penelitian ini adalah tingkat profitabilitas yang dihubungkan dengan menggunakan risiko operasional dan kecukupan modal yang terdapat pada Bank Milik Swasta Nasional periode 2015-2019. Sumber data yang digunakan dalam penelitian ini adalah data sekunder yang diperoleh dari laporan keuangan Bank Milik Swasta Nasional pada periode 2015-2019. Jenis data yang digunakan adalah data kuantitatif dan kualitatif, sedangkan sumber data dalam penelitian ini adalah data sekunder.

Data sekunder yang digunakan dalam penelitian ini adalah laporan keuangan perusahaan perbankan di Bursa Efek Indonesia (BEI) yang berasal dari Laporan tahunan (Annual Report) dan dipublikasikan melalui situs www.idx.co.id. Populasi dalam penelitian ini adalah Perusahaan Perbankan di Bursa Efek Indonesia (BEI) yang berjumlah 6 perusahaan perbankan.

Populasi yang digunakan dalam penelitian ini adalah Bank Umum Swasta Nasional yang terdaftar di Bursa Efek Indonesia, yaitu 6 Bank Umum Swasta Nasional yang bersumber dari website resmi Bank BCA, CIMB NIAGA, DANAMON, MAYBANK, MEGA, dan SINARMAS. Sedangkan sampel penelitian diperoleh dengan teknik purposive sampling yaitu metode pemilihan sampel dengan kriteria tertentu. Adapun kriteria penentuan sampel dalam penelitian ini sebagai berikut: 
1. Terdapat 6 Bank Umum Swasta Nasional yang terdaftar di Bursa Efek Indonesia periode 2015-2019.

2. Bank Umum Swasta Nasional yang menyajikan laporan keuangan selama 5 (lima) tahun secara berturut-turut dari tahun 2015-2019.

3. Bank Umum Swasta Nasional yang menyampaikan laporan keuangan kepada Bursa Efek Indonesia (BEI) sesuai dengan variabel yang diteliti.

4. Bank Umum Swasta Nasional yang menyajikan laporan keuangan secara lengkap dari tahun 2015-2019.

Penelitian ini menggunakan variabel profitabilitas (ROA) sebagai variabel terikat, dan menggunakan variabel bebas yaitu risiko operasional (BOPO), dan kecukupan modal (CAR).

Untuk menguji hipotesis yang telah diajukan dalam penelitian ini, maka teknik analisis data yang akan digunakan adalah:

\section{Analisis Statistik Deskriftif}

Statistik Deskriptif memberikan gambaran atau deskripsi suatu data yang dilihat dari nilai rata-rata (mean), standar deviasi, varians, maksimum dan minimum, sum, range, kurtosis dan skewness (Ghozali, 2016:19).

\section{Uji Asumsi Klasik}

- Uji Normalitas: bertujuan untuk menguji apakah dalam model regresi, variabel pengganggu atau residual memiliki distribusi normal". Model regresi yang baik memiliki distribusi data normal atau mendekati normal. (Ghozali, 2013).

- Uji Multikolinieritas: Menurut Ghozali (2009:95) untuk mengetahui apakah ditemukan adanya korelasi antar variabel bebas. Model regresi yang baik seharusnya tidak terjadi korelasi di antara variabel independen.

- Uji Autokorelasi: digunakan untuk melihat apakah dalam suatu model regresi terdapat korelasi kesalahan pengganggu antara periode saat ini dengan periode sebelumnya (Ghozali, 2011).

- Uji Heteroskedastisitas: digunakan untuk menguji apakah pada model regresi terdapat kesamaan atau ketidaksamaan varians antara pengamatan yang satu ke pengamatan lainnya (Ghozali 2011).

\section{Uji Regresi Linier Berganda}

Analisis regresi berganda adalah merupakan teknik analisis regresi yang digunakan untuk menguji pengaruh beberapa variabel independen terhadap satu variabel dependen (Latan dan Temalagi, 2013:84). Artinya, untuk menguji kekuatan variable independen yaitu risiko operasional dan modal kerja terhadap variable dependen yaitu profitabiltas.

Rumus persamaan regresi yang digunakan adalah sebagai berikut:

$$
\mathrm{Y}=\mathrm{a}+\mathrm{b} 1 \mathrm{X} 1+\mathrm{b} 2 \mathrm{X} 2+\grave{\mathrm{e}}
$$

$$
\begin{aligned}
& \text { Dimana: } \\
& \mathrm{Y}=\text { Profitabilitas (ROA) } \\
& \mathrm{a}=\text { Konstanta } \\
& \mathrm{b}=\text { Koefisien regresi } \\
& \mathrm{X} 1=\text { Risiko Operasional } \\
& \mathrm{X} 2=\text { Kecukupan Modal } \\
& \grave{\mathrm{E}}=\text { Error }
\end{aligned}
$$




\section{Uji Hipotesis}

- Uji Signifikan Persial (t): Digunakan untuk mengetahui apakah variabel-variabel bebas secara parsial berpengaruh nyata atau tidak terhadap variabel terikat. Derajat signifikansi yang digunakan adalah 0,05. Apabila nilai signifikan lebih kecil dari derajat kepercayaan maka kita menerima hipotesis alternatif, yang menyatakan bahwa suatu variabel bebas secara parsial mempengaruhi variabel terikat. Menurut Sugiyono (2008:244).

- Uji Signifikan Simultan (f): Digunakan untuk mengetahui apakah variable-variabel independen secara simultan mempengaruhi variable dependen secara signifikansi. Artinya, dengan dilakukan uji f yaitu menguji pengaruh bersama-sama antara Risiko Operasional dan Kecukupan Modal terhadap Profitabilitas.

\section{HASIL DAN PEMBAHASAN}

Berdasarkan data Laporan Tahunan Perusahaan Perbankan Swasta di Bursa Efek Indonesia tahun 2015-2019, maka rasio-rasio keuangan bank yang digunakan dalam penelitian ini yang meliputi BOPO, CAR dan ROA dapat dihitung. Dapat dilihat pada Tabel 1. berikut ini nilai minimum, maksimum, rata-rata (mean) dan standar deviasi dari masing-masing variabel penelitian.

Tabel

1.

\begin{tabular}{lr|r|r|r|r} 
& \multicolumn{9}{c}{ Statistik Deskriptif } & \multicolumn{1}{c}{$\begin{array}{c}\text { Std. } \\
\end{array}$} & $\begin{array}{c}\text { Minimu } \\
\mathrm{N}\end{array}$ & $\begin{array}{c}\text { Maximu } \\
\mathrm{m}\end{array}$ & \multicolumn{1}{c}{ Mean } & Deviation \\
\hline BOPO & 30 & 58.20 & 119.43 & 81.2047 & 13.15098 \\
\hline CAR & 30 & 14.37 & 26.21 & 20.2600 & 3.07878 \\
\hline ROA & 30 & .23 & 4.00 & 2.1277 & 1.11921 \\
\hline $\begin{array}{l}\text { Valid N } \\
\text { (listwise) }\end{array}$ & 30 & & & & \\
\hline
\end{tabular}

Berdasarkan hasil Tabel 1 menunjukkan bahwa jumlah observasi data yang digunakan pada penelitian ini berjumlah 30 data yang di dapat dari 6 sampel laporan keuangan perusahaan perbankan swasta selama 5 tahun pada periode 2015-2019. Berdasarkan perhitungan selama periode 2015-2019 terlihat bahwa rata-rata ROA bernilai positif yaitu sebesar 2,1277 persen. Hal tersebut menunjukkan bahwa setiap tahunnya selama periode 2015-2019 rata-rata ROA mengalami peningkatan. Standar Deviasi ROA sebesar 1,11921 persen. Pengaruh CAR dan BOP nilai rata-rata ROA sebesar 2.1277 persen. Nilai ROA terendah adalah 0,23 persen dan nilai ROA tertinggi adalah 4,00 persen. 
Tabel 2.

Hasil Uji Normalitas

One-Sample Kolmogorov-Smirnov Test

Unstandardized

Residual

\begin{tabular}{llr}
\hline N & & 30 \\
\hline Normal Parametersa,b & Mean & .0000000 \\
\cline { 2 - 3 } & Std. Deviation & .30879764 \\
\hline Most Extreme Differences & Absolute & .170 \\
\cline { 2 - 3 } & Positive & .170 \\
\cline { 2 - 3 } & Negative & -.146 \\
\hline Test Statistic & & .170 \\
\hline Asymp. Sig. (2-tailed) & & $.026^{c}$ \\
\hline
\end{tabular}

a. Test distribution is Normal.

b. Calculated from data.

c. Lilliefors Significance Correction.

Berdasarkan hasil pengujian uji statistik Kolmogorov-Smirnov (K-S) menunjukan bahwa nilai K-S adalah 0,170. Nilai probabilitas signifikansi adalah 0,026. Nilai tersebut menunjukan bahwa secara statistik probabilitas signifikansi K-S lebih besar dari alpha 0,05 sehingga data nilai residual pada hipotesis penelitian terdistribusi normal.

Tabel 3.

\section{Hasil Uji Multikolinieritas}

\begin{tabular}{lrrr} 
& & \multicolumn{2}{c}{ Collinearity Statistics } \\
Model & & Tolerance & \multicolumn{1}{c}{ VIF } \\
\hline 1 & BOPO & .655 & 1.528 \\
& & & \\
\cline { 2 - 4 } & CAR & .655 & 1.528 \\
\hline
\end{tabular}

a. Dependent Variable: ROA

Berdasarkan hasil uji multikolinearitas di atas menunjukkan bahwa nilai Tolerance dari ke dua variabel independen berada di atas 10\% dan nilai VIF kurang dari 10. 
Tabel 4.

\section{Hasil Uji Autokorelasi}

\begin{tabular}{ll|r|r|r|r} 
& & & & \\
Model & R & R Square & \multicolumn{1}{c|}{$\begin{array}{l}\text { Square } \\
\text { Squared }\end{array}$} & $\begin{array}{c}\text { Std. Error of } \\
\text { the Estimate }\end{array}$ & $\begin{array}{l}\text { Durbin- } \\
\text { Watson }\end{array}$ \\
\hline 1 & $.961^{\mathrm{a}}$ & .924 & .918 & .32003 & 1.439 \\
\hline
\end{tabular}

a. Predictors: (Constant), CAR, BOPO

b. Dependent Variable: ROA

Berdasarkan hasil uji autokorelasi terlihat nilai DW 1,439, dibandingkan dengan nilai tabel signifikansi 5\%, jumlah sampel 30 (n) dan jumlah variabel independen 2 (K=2) maka diperoleh nilai du 1,885. Nilai DW 1,439 lebih kecil dari batas atas (du) yakni 1,885 dan kurang dari (4-du) 4-1,885 =3,324 maka dapat disimpulkan bahwa tidak terjadi autokorelasi.

Tabel 5.

\section{Hasil Uji Heteroskedastisitas}

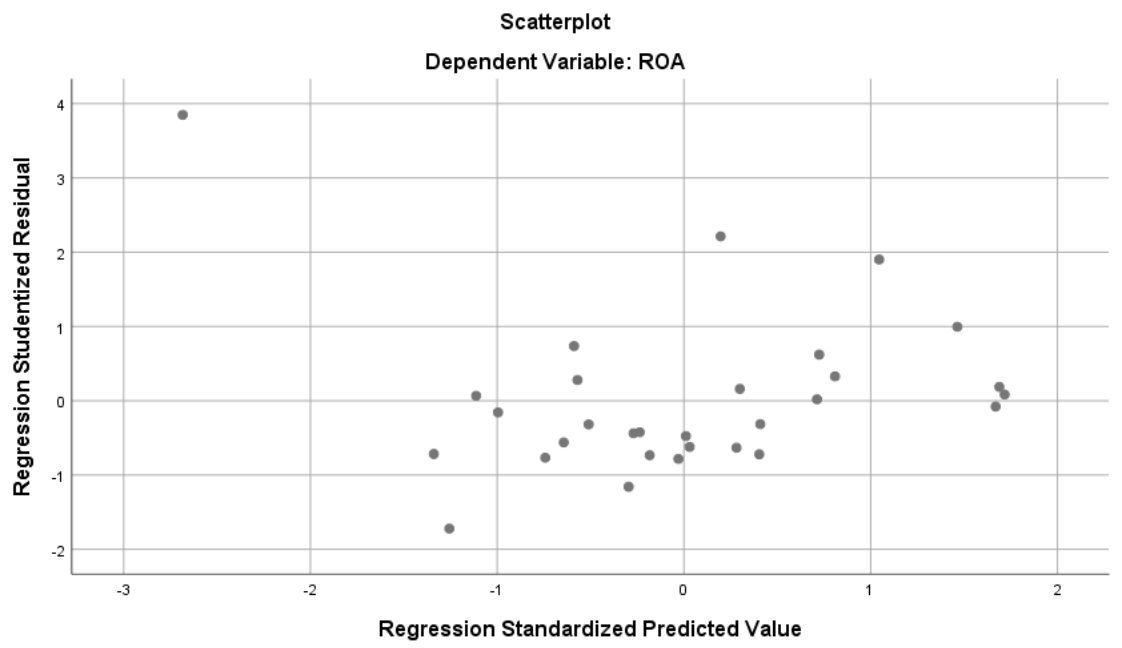

Berdasarkan hasil Uji Heteroskedastisitas, jika titik-titik berada di atas nol maupun di bawah nol maka merupakan model yang baik karena merupakan model yang homoskedastisitas. 
Tabel 6.

Hasil Analisis Regresi Linier Berganda

\begin{tabular}{|c|c|c|c|c|c|c|c|c|c|}
\hline \multirow{2}{*}{\multicolumn{2}{|c|}{ Model }} & \multicolumn{2}{|c|}{$\begin{array}{c}\text { Unstandardized } \\
\text { Coefficients }\end{array}$} & \multirow{2}{*}{$\begin{array}{c}\text { Standard } \\
\text { ized } \\
\text { Coefficie } \\
\text { nts } \\
\text { Beta }\end{array}$} & \multirow[b]{2}{*}{$\mathrm{T}$} & \multirow[b]{2}{*}{ Sig. } & \multicolumn{3}{|c|}{ Correlations } \\
\hline & & B & $\begin{array}{l}\text { Std. } \\
\text { Error }\end{array}$ & & & & $\begin{array}{l}\text { Zero- } \\
\text { order }\end{array}$ & $\begin{array}{c}\text { Partia } \\
1\end{array}$ & Part \\
\hline \multirow[t]{3}{*}{1} & $\begin{array}{l}\text { (Const } \\
\text { ant) }\end{array}$ & 6.141 & .837 & & 7.338 & .000 & & & \\
\hline & $\mathrm{BOPO}$ & -.069 & .006 & -.815 & $\begin{array}{r}- \\
12.422\end{array}$ & .000 & -.945 & -.923 & -.660 \\
\hline & CAR & .080 & .024 & .220 & 3.353 & .002 & .699 & .542 & .178 \\
\hline
\end{tabular}

a. Dependent Variable: ROA

$$
\mathrm{Y}=6.141-0.069 \mathrm{X}_{1}+0.080 \mathrm{X}_{2}+0.837
$$

Dimana:

$\mathrm{Y}=$ Profitabilitas $(\mathrm{ROA})$

$\mathrm{a}=$ Konstanta

$\mathrm{X} 1=$ Risiko Operasional (BOPO)

$b=$ Koefisien regresi

$\mathrm{X} 2=$ Kecukupan Modal (CAR)

$\grave{E}=$ Error

Persamaan regresi linier berganda tersebut menunjukkan arah masingmasing variabel bebas terhadap variabel terikatnya, dimana koefisien regresi variabel bebas yang bertanda negatif berarti mempunyai pengaruh yang berlawanan terhadap ROA sebagai proksi profitabilitas.

Berdasarkan model regresi dan tabel 6 di atas maka hasil regresi berganda dapat dijelaskan sebagai berikut:

- Konstanta: 6.141 artinya besaran konstanta menunjukkan bahwa jika variabel-variabel independen diasumsikan konstan, maka variabel dependen yaitu ROA sebesar $6.141 \%$.

- BOPO: $-0,069$ artinya bahwa setiap risiko operasional meningkat $1 \%$, maka akan mengalami penurunan profitabilitas sebesar $0,069 \%$.

- CAR: 0,080 artinya bahwa setiap kecukupan modal meningkat $1 \%$, maka akan mengalami peningkatan profitabilitas sebesar $0,080 \%$.

- Standar Error: 0.837 artinya bahwa setiap standar error meningkat 1\%, maka akan mengalami peningkatan profitabilitas sebesar $0,837 \%$. 
Pengaruh risiko operasional (X1) terhadap profitabilitas (Y) pada Bank Milik Swasta Nasional Indonesia periode 2015-2019

Tabel 7.

Hasil Uji t (Persial)

\begin{tabular}{|c|c|c|c|c|c|c|}
\hline \multirow{2}{*}{\multicolumn{2}{|c|}{ Model }} & \multicolumn{2}{|c|}{$\begin{array}{l}\text { Unstandardized } \\
\text { Coefficients }\end{array}$} & \multirow{2}{*}{$\begin{array}{c}\text { Standardized } \\
\text { Coefficients } \\
\text { Beta } \\
\end{array}$} & \multirow[b]{2}{*}{$\mathrm{t}$} & \multirow[b]{2}{*}{ Sig. } \\
\hline & & $\mathrm{B}$ & Std. Error & & & \\
\hline \multirow[t]{2}{*}{1} & (Constant) & 8.655 & .434 & & 19.932 & .000 \\
\hline & $\mathrm{BOPO}$ & -.080 & .005 & -.945 & -15.222 & .000 \\
\hline
\end{tabular}

a. Dependent Variable: ROA

Berdasarkan Tabel 7 dapat diketahui berarti HO ditolak dan H0 diterima, hal ini ditunjukan dari nilai t-hitung sebesar -15.222 yang lebih kecil dari t-tabel $=8.655$ dan probabilitas signifikansinya 0.000 lebih kecil daripada $\alpha=0,05$, nilai B sebesar -0.080 menunjukkan arah negatif. Jadi dapat disimpulkan bahwa BOPO berpengaruh negatif terhadap ROA. Ini berarti hasil pengujian hipotesis ini menerima hipotesis $\mathrm{H}_{1}$ yang menyatakan bahwa BOPO berpengaruh negatif secara signifikan terhadap CAR.

Pengaruh tingkat kecukupan modal (X1) terhadap profitabilitas (Y) pada Bank Milik Swasta Nasional Indonesia periode 2015-2019

Table 8.

Hasil Uji t (Persial)

\begin{tabular}{|c|c|c|c|c|c|c|}
\hline \multirow{2}{*}{\multicolumn{2}{|c|}{ Model }} & \multicolumn{2}{|c|}{$\begin{array}{l}\text { Unstandardized } \\
\text { Coefficients }\end{array}$} & \multirow{2}{*}{$\begin{array}{c}\text { Standardized } \\
\text { Coefficients } \\
\text { Beta } \\
\end{array}$} & \multirow[b]{2}{*}{$\mathrm{t}$} & \multirow[b]{2}{*}{ Sig. } \\
\hline & & $\mathrm{B}$ & Std. Error & & & \\
\hline \multirow[t]{2}{*}{1} & (Constant) & -3.022 & 1.006 & & -3.003 & .006 \\
\hline & CAR & .254 & .049 & .699 & 5.175 & .000 \\
\hline
\end{tabular}

a. Dependent Variable: ROA

Berdasarkan Tabel 8 dapat diketahui H0 ditolak dan H0 diterima, hal ini ditunjukan dari nilai t-hitung sebesar 5.175 yang lebih besar dari $\mathrm{t}$-tabel $=-3.022$ dan probabilitas signifikansinya 0,000 lebih kecil daripada $\alpha=0,05$, nilai B sebesar 0,254 menunjukkan arah positif. Jadi dapat disimpulkan bahwa CAR berpengaruh positif terhadap ROA. Dapat disimpulkan bahwa hasil pengujian hipotesis ini menerima hipotesis $\mathrm{H}_{2}$ yang menyatakan bahwa CAR berpengaruh positif secara signifikan terhadap CAR. 
Tabel 9.

Hasil Uji f (Simultan)

ANOVA $^{\mathrm{a}}$

\begin{tabular}{|c|c|c|c|c|c|c|}
\hline \multicolumn{7}{|c|}{ ANOVA $^{a}$} \\
\hline \multicolumn{2}{|c|}{ Model } & $\begin{array}{l}\text { Sum of } \\
\text { Squares }\end{array}$ & Df & $\begin{array}{l}\text { Mean } \\
\text { Square }\end{array}$ & $\mathrm{F}$ & Sig. \\
\hline \multirow[t]{3}{*}{1} & Regression & 33.561 & 2 & 16.780 & 163.840 & $.000^{\mathrm{b}}$ \\
\hline & Residual & 2.765 & 27 & .102 & & \\
\hline & Total & 36.326 & 29 & & & \\
\hline
\end{tabular}

a. Dependent Variable: ROA

b. Predictors: (Constant), CAR, BOPO

Berdasarkan Tabel 9 dapat diketahui H0 ditolak dan H0 diterima, hal ini ditunjukkan H0 ditolak dengan nilai F-hitung $=163.840>$ F-table $=33.561$, ada pengaruh yang signifikan antara Risiko Operasional dan Kecukupan Modal terhadap Profitabilitas. Dapat di simpulkan bahwa hasil pengujian hipotesis ini menerima hipotesis $\mathrm{H}_{3}$ yang menyatakan terdapat pengaruh Risiko Operasional dan Kecukupan Modal secara simultan terhadap ROA.

\section{SIMPULAN DAN SARAN}

Berdasarkan pembahasan yang telah diuraikan sebelumnya, maka diperoleh simpulan sebagai berikut: 1). Risiko Operasional (BOPO) secara parsial berpengaruh negatif secara signifikan terhadap Pofitabilitas (CAR) pada Bank Milik Swasta Nasional Indonesia periode 2015-2019. Pengaruh negatif yang ditunjukkan nilai t-hitung sebesar -15.222 yang lebih kecil dari $\mathrm{t}$-tabel $=8.655$ dan probabilitas signifikansinya 0.000 lebih kecil daripada $\alpha=0,05$, nilai B sebesar -0.080 menunjukkan arah negatif. 2). Kecukupan Modal (CAR) secara parsial berpengaruh positif secara signifikan terhadap Pofitabilitas (CAR) pada Bank Milik Swasta Nasional Indonesia periode 20152019. Pengaruh positif yang ditunjukkan nilai t-hitung sebesar 5.175 yang lebih besar dari $t$-tabel $=-$ 3.022 dan probabilitas signifikansinya 0,000 lebih kecil daripada $\alpha=0,05$, nilai B sebesar 0,254 menunjukkan arah positif.

Adapun saran yang bisa diberikan bagi perusahaan Bank Milik Swasta Nasional di Bursa Efek Indonesia diharapkan selalu menjaga dan menstabilkan tingkat kecukupan modalnya, sehingga dapat meningkatkan Profitabilitas perbankan. Perusahaan perbankan harus berhati-hati sebab penambahan modal tambahan sewaktu-waktu bisa berubah yang mengakibatkan penurunan, serta memperhatikan risiko operasional (BOPO) agar tidak terjadinya kenaikan.

\section{DAFTAR PUSTAKA}

Anita, N. (2016). Analisis Perbandingan Kinerja Keuangan Bank Pemerintah (BUMN) Dan Bank Swasta Nasional Yang Terdaftar Di Bursa Efek Indonesia (BEI). http://repositori.uinalauddin.ac.id/6160/1/Nur Anita.pdf

Anjani, Dewa Ayu. 2014. Pengaruh Non Performing Loan (NPL), Likuiditas, dan Rentabilitas Terhadap Rasio Kecukupan Modal. E-Jurnal Program Studi Manajemen Fakultas Ekonomi dan Bisnis Universitas Udayana, 3(4), h: 1140- 1155.

Antariksa, Riki. 2005. "Pengaruh Resiko Liquiditas terhadap Profitabilitas (Studi Kasus pada PT. Bank Muamalat Indonesia)." Jurnal ekonomi Keuangan dan Bisnis Islami. 
Dendawijaya, Lukman. 2009. Manajemen Perbankan. Edisi Revisi. Bogor: Ghalia Indonesia.

Ghozali, Imam. 2009. Aplikasi Analisis Multivariate dengan Program SPSS. Cetakan ke IV. Semarang: BP UNDIP.

Haeriah, T. (2015). Risiko Operasional. Fhayluzhia.Blogspot.Com.

http://fhayluzhia.blogspot.com/2015/06/risiko-operasional.html

Kasmir. 2012. Bank dan Lembaga Keuangan Lainnya. Edisi Revisi. Jakarta: PT Rajagrafindo Persada.

Prasetyo, D., \& Darmayanti, N. (2015). Pengaruh Risiko Kredit, Likuiditas, Kecukupan Modal, Dan Efisiensi Operasional Terhadap Profitabilitas Pada Pt Bpd Bali. E-Jurnal Manajemen Universitas Udayana, 4(9), 253294.

Ratio, P. R. (2016). Pengaruh Ratio-Ratio Keuangan CAR, LDR, NIM, BOPO, NPL Terhadap ROA. Jurnal Riset Bisnis Dan Manajemen, 4(1), 67-82.

Wahyuni Pratiwi, L., \& Wiagustini, N. (2016). Pengaruh Car,Bopo,Npl Dan Ldr Terhadap Profitabilitas. E-Jurnal Manajemen Universitas Udayana, 5(4), 255168.

www.bca.co.id

www.danamon.co.id

www.idx.co.id

www.maybank.co.id

www.bankmega.com/id

www.banksinarmas.com/id 